\title{
Geophysical modeling of Serra Negra and Salitre I, II and III alkaline-carbonatite complexes based on their gravimetric and magnetic signatures
}

Roberto Paulo Zanon dos Santos, IAG/USP, Marta Silvia Maria Mantovani, IAG/USP, Yara Regina Marangoni, IAG/USP.

Copyright 2019, SBGf - Sociedade Brasileira de Geofísica

This paper was prepared for presentation during the $16^{\text {th }}$ International Congress of the Brazilian Geophysical Society held in Rio de Janeiro, Brazil, 19-22 August 2019.

Contents of this paper were reviewed by the Technical Committee of the $16^{\text {th }}$ International Congress of the Brazilian Geophysical Society and do not necessarily represent any position of the SBGf, its officers or members. Electronic reproduction or storage of any part of this paper for commercial purposes without the written consent of the Brazilian Geophysical Society is prohibited.

\section{Abstract}

The alkaline complexes of Serra Negra and Salitre I, II and III are part of the Alto Paranaíba Igneous Province (APIP), which has been subject of many mining projects due to its important content in mineral resources as phosphates, niobium, titanium, among others. The gravimetric and magnetic anomalies caused by the complexes displays mutual interference becoming difficult to suit individual interpretations. This paper shows the results of $3 \mathrm{D}$ modelling of the anomalies and compares the results with the geological known information.

\section{Introduction}

The Alto Paranaíba Igneus Province (APIP) (Fig. 1) is an assembly of mafic to ultramafic and potassic to ultrapotassic magma intrusions that are aged in the Late Cretaceous (Campos and Dardenne, 1997). The rocks of the complexes include kamafugites, kimberlites, peridotites, lamproites, alkaline-carbonatite with phlogopite-picrites, dunites, bebedourites, sienites, carbonitites and phoscorites disposed in pipes, plugs, diatremes, lava flows and plutonic intrusions( Gibson et al., 1995; Marangoni and Mantovani, 2013 ).

The alkaline-carbonatites of Araxá, Tapira and Catalão I and II that belongs to the APIP's province are already been exploited for then mineral resources of phosphates and Niobium and have known deposits of Titanium and REE ( Brod et al, 2004 ). Many studies of complexes of Serra Negra and Salitres I, II and III have been produced in the last few years to understand their origin, evolution and geometry as well as their mineral resources ( Grasso, 2010; Uliana, 2010 ).

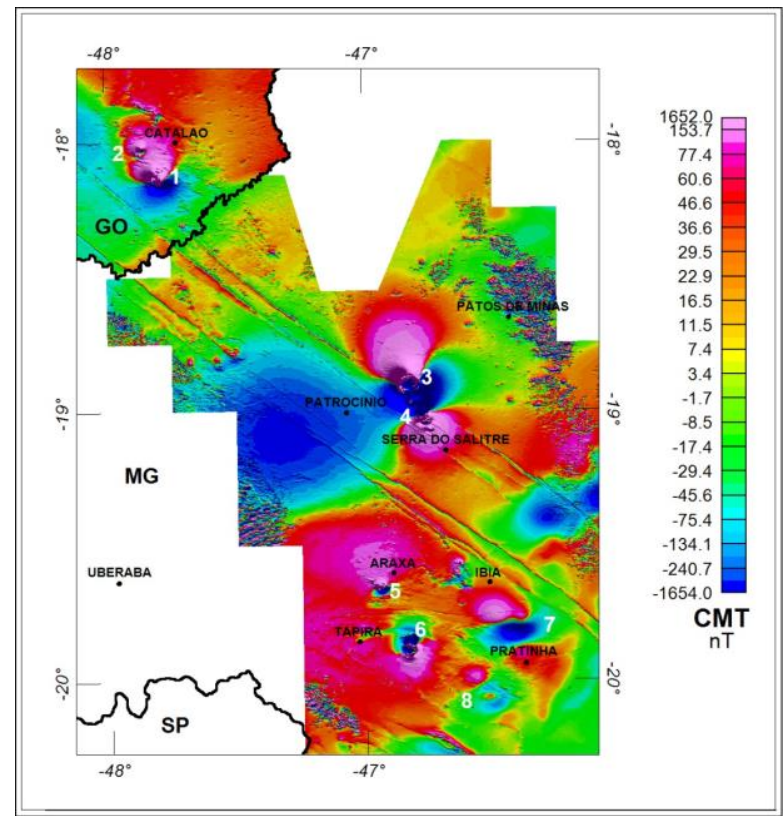

Fig. 1. Total magnetic field anomaly map (nT) for the APIP. Numbers in white indicate alkaline complex locations: 1-Calalão, 2-Catalão 2, 3-Serra Negra, 4-Salitre I, II and III, 5-Araxá (Barreiro), 6-Tapira, 7-Pratinha 1, 8Pratinha 2. Regional importante cities and state borders are marked in black (extracted from Marangoni and Mantovani, 2013).

The gravimetric and magnetic signatures of the complexes are very distinctive compared to the host rocks and when studied jointly can reduce the amount of ambiguity which is inherent to the potential field methods. The goal of the present study is to compare the results from different approaches by inversion and direct modelling using the magnetic and gravimetric data available over the target and evaluate them with the geological knowledge of the complexes.

\section{Geological Context}

The Serra Negra and Salitres complexes are located close to Patrocínio city at Minas Gerais state. Both of them are intrusions in the Canastra group formed of quartizites and metasedimentary rocks.

Serra Negra has a circular shape of approximately $10 \mathrm{Km}$ of diameter. Mariano \& Marchetto (1991) describes the complex as formed by Calcium Carbonatite in his center with apatite, dolomite and minor parts of phlogopite, 
magnetite, humite, rutile, pyrochlor, pyrrhotite and pyrite. Amaral et al. (1967) showed ages between 83.7 and 83.4 Ma for the complex. The geological map of Serra Negra is shown in Fig. 2.

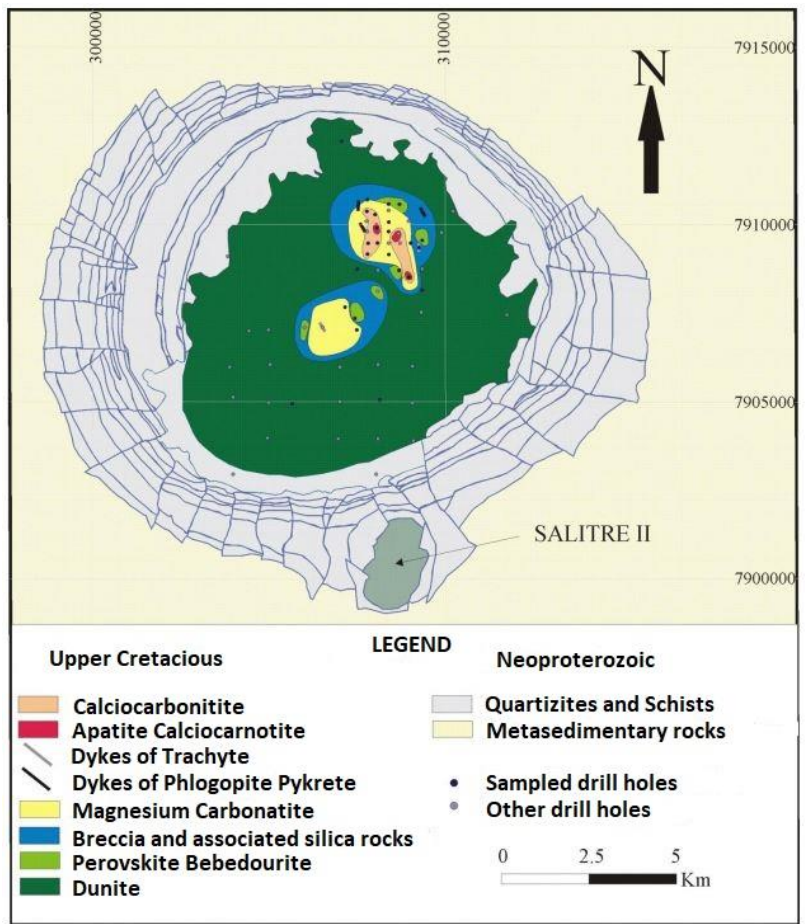

Fig . 2 - Geological Map of Serra Negra alkaline complex modified from Grasso (2010).

Barbosa et al. (2012) describes the Salitre I alkaline complex as a plutonic intrusion with the lithotype predominance of Bebedourites, Phoscorites and carbonitites. According to Sonoki \& Garda (1988) the K/Ar dating at phlogopites in Bebedourites gives the age of $86.3 \pm 5.7 \mathrm{Ma}$ for the complex. The geological Map of Salitre $\mathrm{I}$ is shown in Fig. 3.

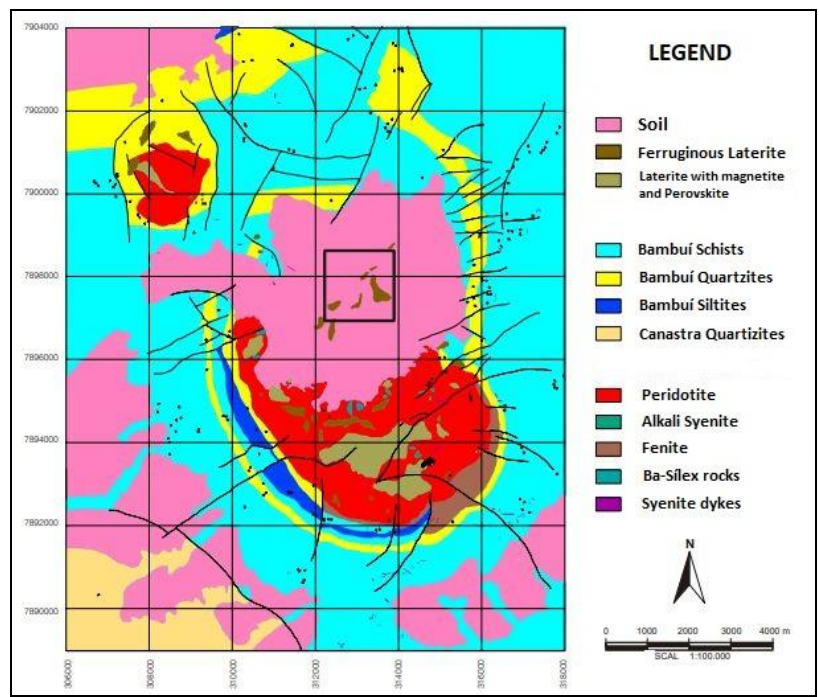

Fig. 3. The Geological Map of Salitre I and II modified from Uliana (2010).
Salitre III is described as small occurrence south to Salitre II with approximately $1,7 \mathrm{Km}$ of diameter. According to Dnpm and Fosfértil presentation for the mining prospects it has Bebebourites and Laterites of Bebedourites as it's major components. The geological map of Salitre III is presented in Figure 4.

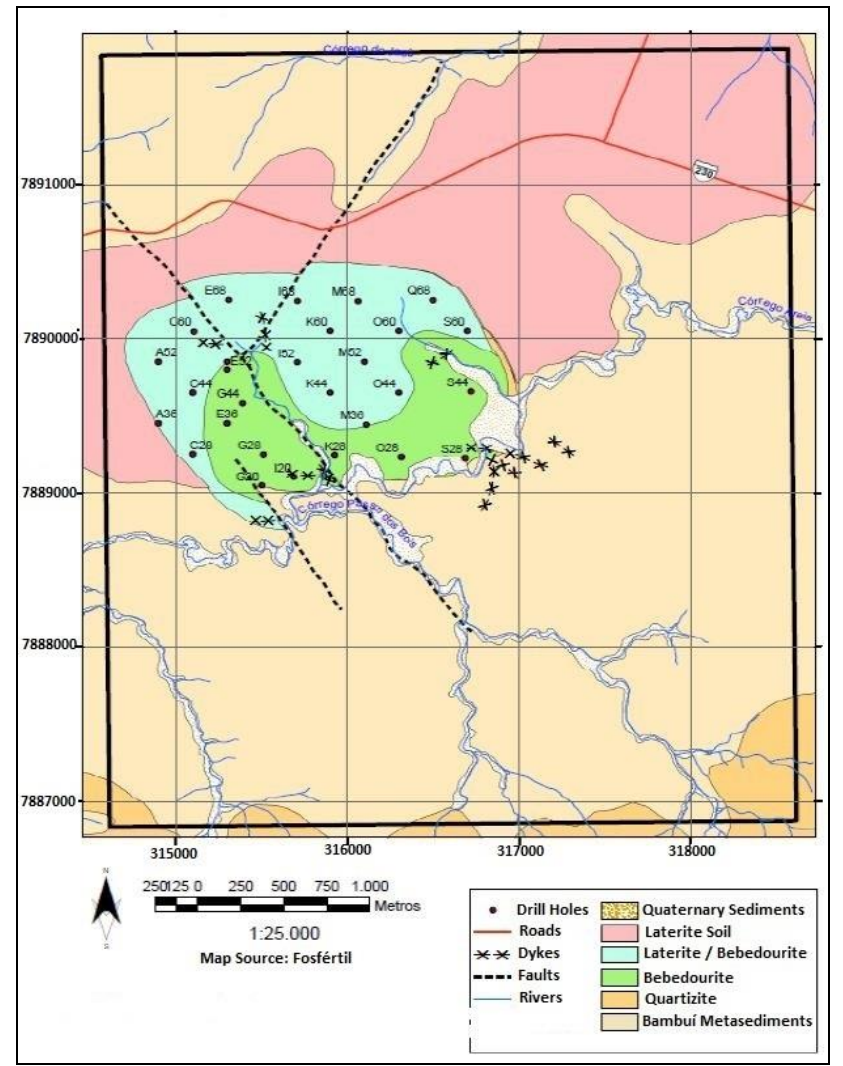

Fig. 4 - Geological Map of Salitre 3 akaline complex modified from Fonseca (2009).

\section{Method}

\section{Magnetometry}

The magnetic data in this study was the geophysical airborne survey Área 7 from CODEMIG/CPRM (Brazilian geological agencies) flown between 2005 and 2006. The survey lines have north-south direction and are $400 \mathrm{~m}$ apart. The mean survey terrain clearance was $100 \mathrm{~m}$. The magnetic data was collected at $10 \mathrm{~Hz}$ sample rate. The Total Magnetic Field were gridded using the minimum curve method with the cell size of $1 / 4$ of the line space separation $(100 \mathrm{~m})$. The final data were levelled and microlevelled for noise removal and the International Geomagnetic Reference Field (IGRF) extracted. The main database was cut to the study area over the anomalies (Fig. 5). 


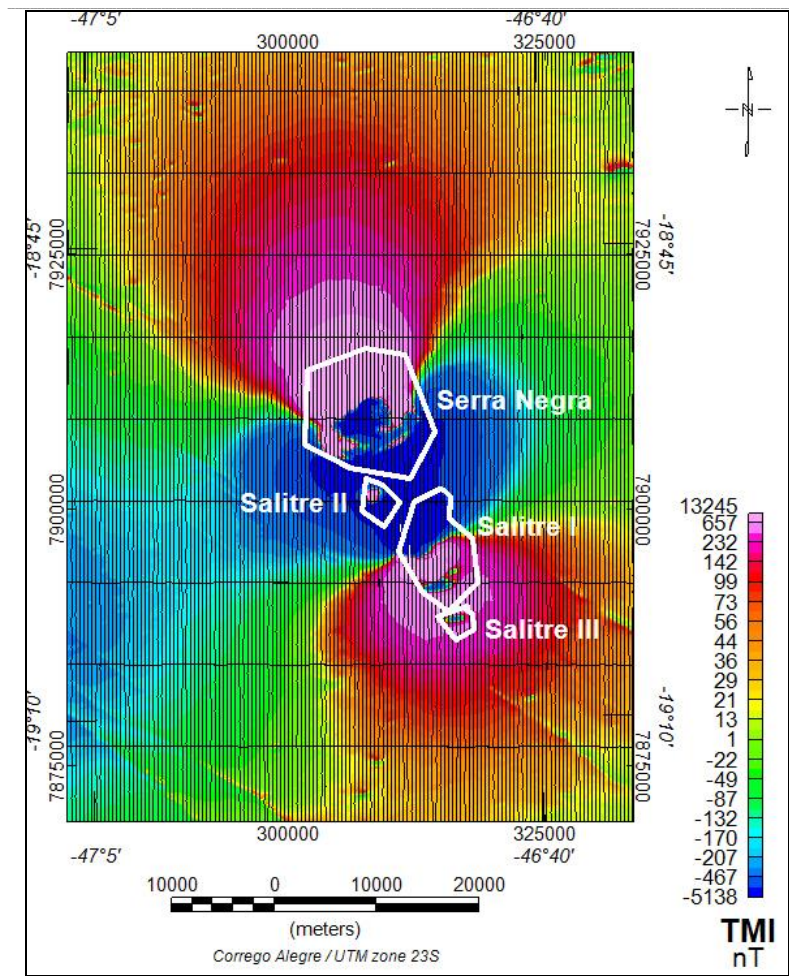

Fig. 5. The residual magnetic field from Serra Negra and Salitre I, II and III. The flight lines are in black.

\section{Forward Modelling}

The magnetic forward modelling for the anomalies were obtained using the Modelvision software which assembles a algorithm based on Barnet (1976). The analytical method developed proposes the representation of any arbitrarily polyhedron bodies as composed by a number of finite triangular facets and computes the magnetic field for each facet. The field expression for the whole polyhedron body will be the sum of the each triangle contribution. The software also have the flexibility to use any magnetic information for the bodies as the magnetic remanence or anisotropy.

\section{Inversion Modelling}

The inversion modelling for the anomalies were achieved using the Magnetization Vector Inversion (MVI) technique wich is part of Oasis Montaj software. The MVI was presented by Ellis et al (2012) and incorporate remanent and induced magnetization in the inversion algorithm. The autors uses equations between the magnetization components and magnetic anomalies and then optimized the objective function to obtain three components of magnetization vector with the same regularization parameters used in scalar inversions.

Gravimetry
The ground gravimetric data used in this study were acquired by IAG/USP for various projects between 2001 and 2012 totaling 348 stations over all the alkaline complexes. it was used the Lacoste-Romberg model $G$ gravimeter for the acquision of gravity data. The altimetry was obtained using gps with differencial correction allowing precision at about $0.1 \mathrm{~m}$. The Bouguer anomaly were calculated using $2,67 \mathrm{~g} / \mathrm{cm}^{3}$ as density background. The grid was generated using minimum curvature with $300 \mathrm{~m}$ cell size. The residual Bouguer was calculated using The Bouguer anomaly map is presented at Fig. 6.

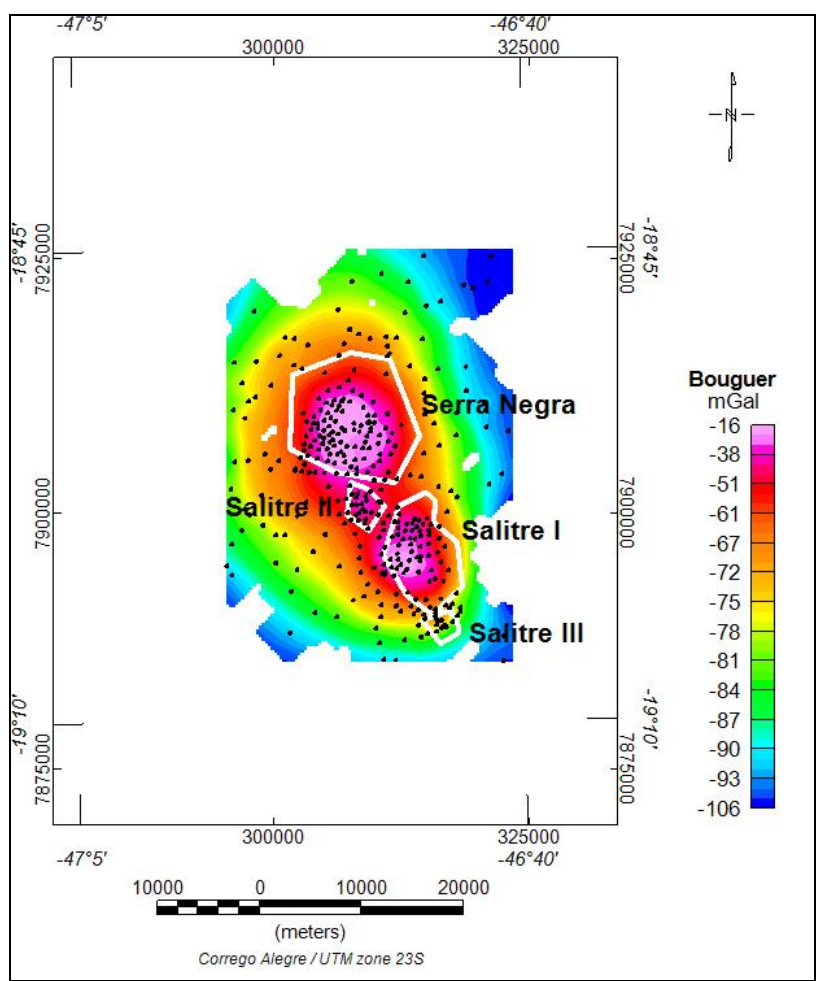

Fig. 6. The Bouguer anomaly map from Serra Negra and Salitres I, II and III. The gravimetric stations are the black dots.

\section{Inversion Modelling}

We have used the UBC-GIF GRAV3D software to make the inversion of the gravimetric data over the anomalies. The algorithm is based on Li and Oldenburg (1998), wich bases the inversion as a optimization problem of a objective function, in this case, density contrast, that is minimized for determined constraints reproducing the observed data over an error tolerance.

\section{Results}

\section{MAG/GRAV Forward Modelling}

For preliminary to model, the Bouguer anomaly grid was sampled to the aeromagnetic survey, so we could use the same database for both methods. Using the amplitude of the analytic signal of the TMI and the geological maps, we 
contoured the borders of Serra Negra and Salitre's bodies and try to fit the major shape of the combined anomalies. We have supposed all bodies as plugin prisms and varying its physical properties to adjust the models. The starting remanent magnetization for the reversed anomalies was extracted form Louro (2013). The proposed densities were extracted from Telford et al. (1992).

The final result have considered the time consuming of modelling of all possible magnetic anomalies observed in the profiles, the adjustment between modeled and observed data over the several lines that crossed the bodies and the residual grid from the model and observed data.

The models are presented in the Figures 7,8 and 9.

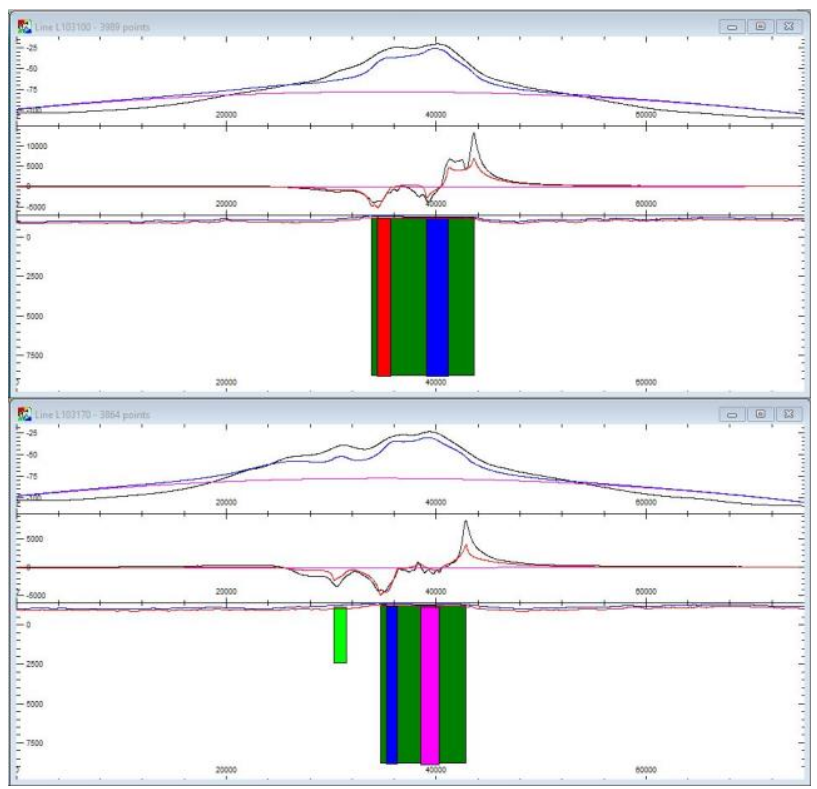

Fig. 7. Flight lines 103100 and 103170 showing the gravity (top) and magnetic (middle) profiles over the suggested anomaly bodies from Serra Negra and Salitre II. The inner bodies were based on the geological maps and observed anomalies within the complexes.

The final proposed density and magnetic values for the bodies differs from the initials as we insert more inner bodies within the complexes in order to better adjust the profiles.

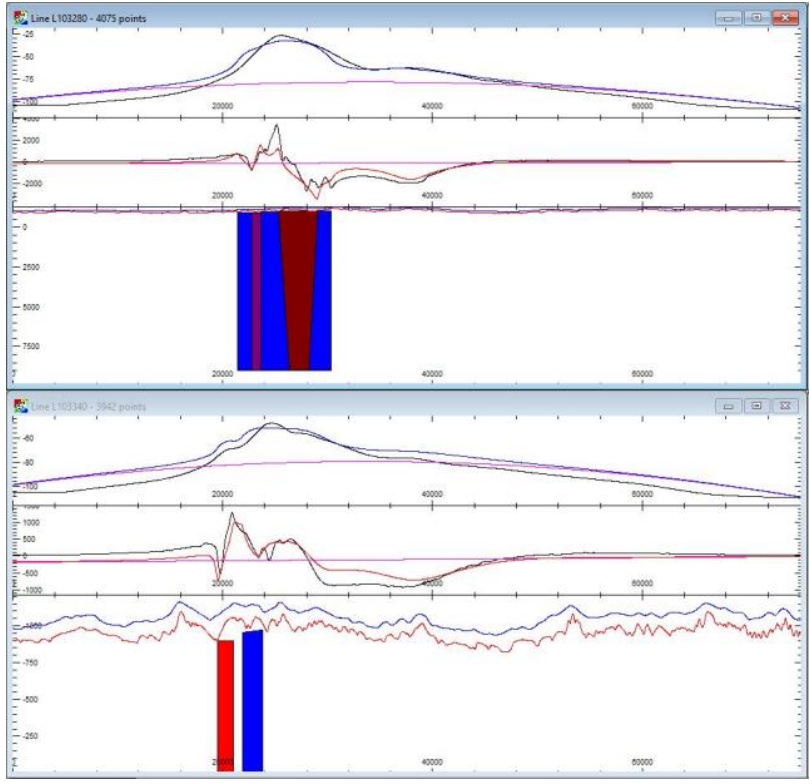

Fig. 8. Flight lines 103280 and 103340 showing the gravity (top) and magnetic (middle) profiles over the proposed anomaly bodies from Salitre I and Salitre III. The inner bodies were based on the geological maps and observed anomalies within the complexes.

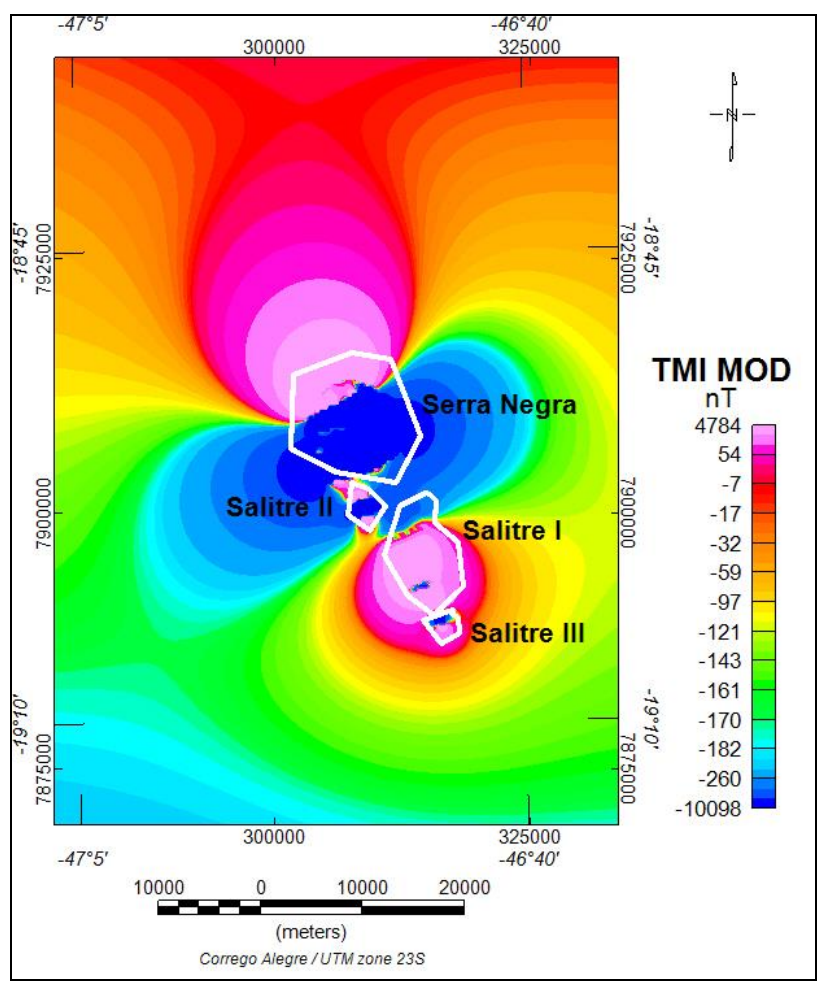

Fig. 9. The total magnetic intensity map from the forward modelled bodies.

The MVI inversion 
We used the same database for the MVI inversion. We have chosen $400 \mathrm{~m}$ for the horizontal cell size and $150 \mathrm{~m}$ for the vertical in the voxi mesh. For the inicial inversions we have not put or changed any constraints or parameters. In the subsequent inversions, we changed the radius of influence, the error attributed to each data and IRI focus as discussed by Pereira et al (2013). The final results were considered very satisfied as it shows clearly the reversed vectors of the magnetization from the anomalies and the shape of the bodies are according to the geological perspective for the alkaline complexes. The amplitude of the apparent susceptibility and the shape recovered from the inversion were also reasonable with a $0.5 \mathrm{SI}$ average for all complexes together.

The model results from the MVI are shown in the figures 10 and 11.

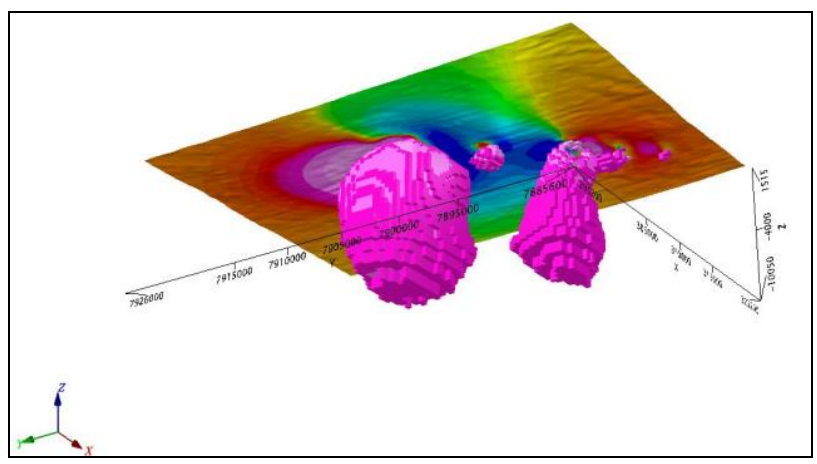

Fig. 10. The $0.07 \mathrm{SI}$ apparent susceptibility clipped surface showing the Serra Negra and Salitre I, II and III bodies.

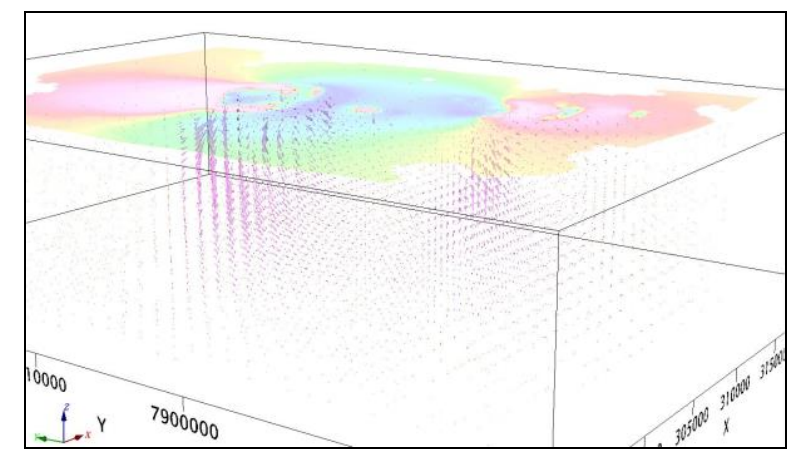

Fig. 11. The magnetization intensity vector recovered from the MVI inversion showing the different magnetization directions for the complexes, including within the same as shown in Serra Negra complex.

\section{Gravity Inversion}

In inversion in the GRAV3D software, we have used 348 gravity stations acquired irregularly spaced all over the complexes. The residual Bouguer anomaly was calculated considering the regional field as just a constant plane of $100 \mathrm{mGal}$. We started the inversions using the GCV trade of to the misfit parameter and used the final results for the subsequent inversions. The mesh cells had $500 \mathrm{~m}$ horizontally and $100 \mathrm{~m}$ in vertical. After each inversion, we have evaluated the results and changed some parameters described by UBC-GIF workflow internet page trying to refine the model. The final result was considered good as it in accordance with the previous methods applied and the geological available information. The gravimetric models obtained are presented in the figures 12 and 13. The final results are shown together in the same mesh to allow the simultaneous visualization in the figure 14.

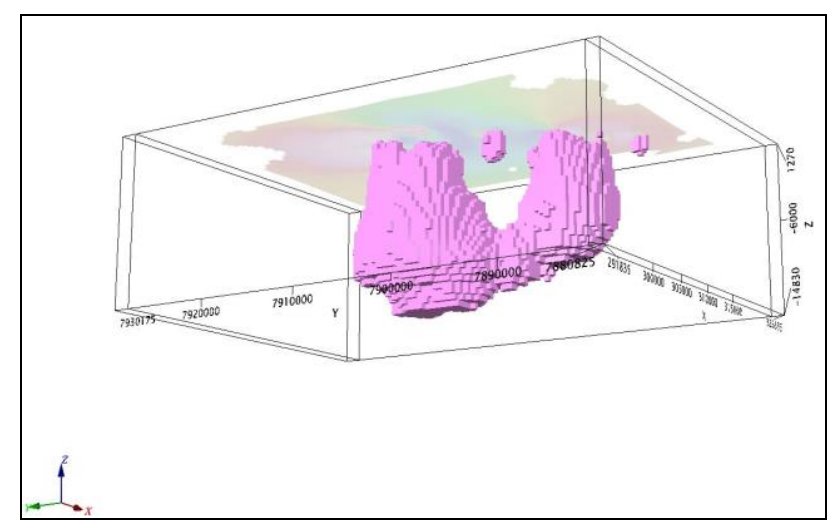

Fig. 12. The $0.3 \mathrm{~g} / \mathrm{cm}^{3}$ recovered density contrast clipped surface showing the Serra Negra and Salitre I, II and III bodies.

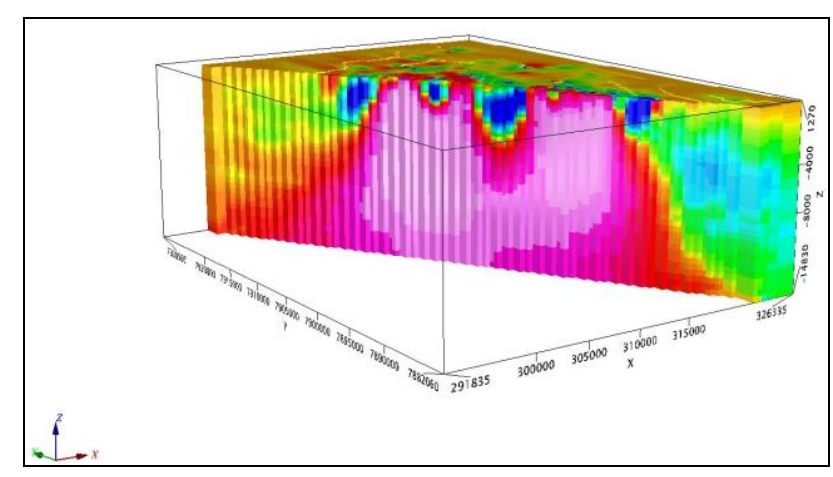

Fig. 13. The amplitude of density contrast sliced at N340W to show the inner part of the models recovered.

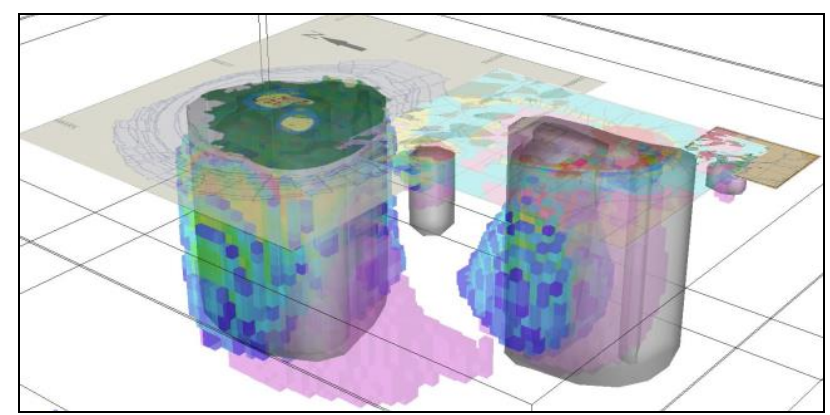

Fig. 14. The three different models in the same mesh. The magenta representing the gravity inversion, the blue to yellow representing the magnetic inversion and in grey the forward magnetic modelling and geological maps. 


\section{Conclusions}

In this study we have presented three different techniques for modelling the magnetic and gravimetric signature from Serra Negra and Salitres I, II and III. All the procedures showed good results when compared with previous studies of the complexes. The forward modelling demand more time, however it allows the user to get more skills over magnetic signatures and their parameters such as remanent magnetization, geometry of the bodies, etc. The inversions software's used in this study required less processing and time consuming, nevertheless resulted in very good models that are all according to the geological perspectives for the alkaline complexes. The MVI has proved to give an excellent tool to magnetic anomalies that have remanent magnetizations.

\section{Acknowledgments}

We thank to CODEMIG and CPRM for providing the geophysical airborne data used in the study. We also thank to CETEM from providing the presentation of Salitre phosphate mining prospect and the geological maps of the complexes. We are grateful to the UBC-GIF group for providing the academic use of grav3d version 3.0 software developed under the consortium research project Joint/Cooperative Inversion of Geophysical and Geological Data, UBC-Geophysical Inversion Facility, Department of Earth and Ocean Sciences, University of British Columbia.

Financial support was provided by CNPq and FAPESP.

\section{References}

Amaral, G., Bushee, J., Cordani, U.G., Kawashita, K., Reynolds, J.H. 1967. Potassium - argon ages of alkaline rocks from Southern Brazil. Geochimica et Cosmochimica Acta 31: 117-142.

Barnett, C. T., 1976. Theoretical modeling of the magnetic and gravitational fields of an arbitrarily shaped threedimensional body. Geophysics, 41, 1353-1364.

Barbosa, E. S. R., Brod, J. A., Cordeiro, P. F. O., BrodJunqueira, T. C., 2012. Variações composicionais de olivinas do complexo alcalino-carbonatítico de Salitre, MG. Revista Brasileira de Geociências, 42(4), pp. 729743.

Brod, J. A., Ribeiro, C. C., Gaspar, J. C., Junqueira-Brod, T. C., Barbosa, E. S. R., Riffel, B. F., Silva, J. F., Chaban, N., Ferrari, A.L.D., 2004. Excursão 1. Geologia e mineralização dos complexos alcalino-carbonatíticos da Província Ígnea do Alto Paranaíba. In: Congresso Brasileiro de Geologia, 42, Guias de Excursões. 1-29. (CDROM). Araxá.

Campos, J. E. G. Dardenne, M. A., 1997. Origem e evolução tectônica da bacia Sanfranciscana. Revista Brasileira de Geociências, 27(3), pp. 283-294.

Ellis, R. G., Wet, B, Macleod, I. N., 2012. Inversion of Magnetic Data from Remanent and Induced Sources. In:
Australian Society of Exploration Geophysicists (ASEG) Extended Abstracts 2012, 22 Conference, pp. 1-4.

Fonseca, D. S., 2009. A jazida de Fosfato de Patrocínio Serra do Salitre http://www.cetem.gov.br/agrominerais/documentos/oficina 3/Apresentacao06.pdf , date: 15/03/2019.

Gibson, S. A., Thompson, R. N., Leonardos, O. H., Dinkin, A. P., Mitchell, J. G., 1995. The late cretaceous impact of the Trindade Mantle plume: evidence from large volume mafic, potassic magmatism in SE Brazil. Jornal of Petrology, 36, 189-229.

Gomes, C. B., Comin-Chiaramonti, P., 2005. Some notes on the Alto do Paranaíba Igneous Province. In: Mesozoic to Cenozoic alkaline magmatism in the Brazilian platform. EDUSP/FAPESP, São Paulo, 752 p.

Grasso, C. B., 2010. Petrologia do complexo alcalinocarbonatítico de Serra Negra, MG. Dissertação de Mestrado, Universidade de Brasília, Brasília, 157 p.

Li, Y. and Oldenburg, D.W. 1998, 3-D Inversion of Gravity Data, Geophysics, vol 63, 109-119.

Louro, V. H. A., 2013. Procedimentos de Análise em Magnetometria: Estimativa de Magnetização Remanente visando inversões para exploração mineral. Dissertação de mestrado, Universidade de São Paulo, São Paulo, 171 p.

Marangoni, Y. R., Mantovani, M. S. M., 2013. Geophysical signatures of the alkaline intrusions bordering the Paraná Basin. Journal of South American Earth Sciences, 41, 83-98.

Mariano, A. N., Marchetto, M., 1991. Serra Negra and Salitre carbonatite alkaline igneous complex. In: Leonardos, O. H., Meyer, H. O. A., Gaspar, J. C. (eds.). In: 5th International Kimberlite Conference Araxá, Field Guide Book, CPRM, Special Publication 3/91, p. 75-79.

Pereira, J. G., Ando, J. L., Barbosa, R. D., Aisengart, T., Pardal, M., 2015. In: Fourteenth International Congresso f the Brazilian Geophysical Society, Rio de Janeiro.

Sonoki, I. K., Garda, G. M., 1988. Idades K-Ar de rochas alcalinas do Brasil Meridional e Paraguai Oriental: compilação e adaptação às novas constantes de decaimento. Boletim IG-USP. Série Científica, 19, pp. 6385.

Telford, W. M., Geldart, L. P., Sheriff, R. E., Keys, D. A., 1990. Applied Geophysics, 2nd edition. Cambridge University Press. 770 p.

Uliana, D. 2010, Caracterização tecnológica do minério de fosfato do complexo alcalino de salitre, MG - área Fosfertil. Dissertação de Mestrado, Universidade de São Paulo, São Paulo, 210p.. 